\title{
ANALYSIS OF THE CHANGING ROLE OF POUND STERLING WITHIN THE INTERNATIONAL MONETARY SYSTEM
}

\author{
Garri Teslya \\ Tatiana Podolskaya \\ Russian Presidential Academy of National Economy and Public Administration (RANEPA), \\ Rostov-on-Don, Russia
}

The paper investigates how the role of the British currency has been changing within the international monetary system. This article is focused on sorting out why the world financial dominance of the United Kingdom was undermined and when exactly the dollar took over as the leading international currency. This question arises, because some authors, using evidence from the bond markets, state that the US dollar overtook sterling much earlier than in 1945, namely in 1929, while others adhere to another common opinion. Our study uses the quantitative research approach to examine the hypothesis questions. The null hypothesis states that the sterling lost its financial dominance before the World War II, while our alternative hypothesis claims that the dominance was lost after the same war.

Keywords: pound sterling; US dollar; currency; international monetary system

\section{Introduction}

The main mission of the international monetary system is consistent control over the financial environment which includes financial institutions, investors and multinational corporations. Basically, IMS can be defined as the system that sets rules and procedures for international payments, determination of exchange rates and capital movements.

\section{Garri Teslya}

MBA, Russia Presidential Academy of National Economy and Public Administration, Rostov-on-Don, Russia

Research interests: financial mathematic, financial markets, currency parity

E-mail: teslya.garry@ranepa.ru

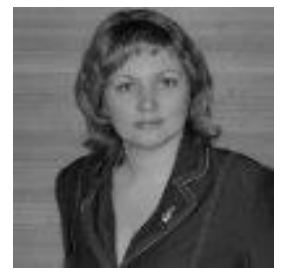

\section{Tatiana Podolskaya}

is a candidate of economical sciences (since 2003); $\mathrm{PhD}$ - candidate in Russia Presidential Academy of National Economy and Public Administration, Rostov-on-Don, Russia (since 2008) and associate professor of department of international economy.

Her scientific interests are concentrated around international financial system, government and international regulation of global finance market.

Since 2005 she published more than 20 articles in Russian federal and international journals; participated more than 30 International scientific - practical conferences.

E-mail: tv.kuraeva@mail.ru 


\section{ANALYSIS OF THE CHANGING ROLE OF POUND}

This is the system responsible for the operation of the financial part of the economy. In its long history it went through four different stages of evolution.

During the era of bimetallism (before 1870), both gold and silver were used as the key means of payment. Later on, IMS transitioned to the fixed exchange rates of the gold standard (up to 1914) and afterwards there was no sustained multipurpose system, but there was a little adherence observed to the previously implemented gold standard. The period of floating exchange rates took place during 1914-1945, which was later substituted by the Bretton-Woods pegged exchange rate system (1945-1973), and then came the times of the managed floating system, which is used till now. Exactly during this time frame of transition from one standard to another, the dominant currency has changed from the pound sterling at the beginning of the century to the US dollar - the only currency now converting to gold. It became the basis for the Bretton Woods system (Södersten \& Reed, 2015).

The main aim of our research is to define the reasons why pound sterling lost its financial dominance and also to study the consequences that British currency has faced. For this, we are planning to use both statistical and theoretical data.

\section{Literature Review}

Critical analysis of the articles written by different authors on the topic of our research is the key means of getting all necessary data and information. Analyzing the already published studies, we will come to our own conclusions. Researchers working in this area are usually divided into two different groups: majority of authors take the view that pound sterling has lost its title of the leading international currency in the early 1900s, while some other authors state that it happened in the mid-1900s.

To begin with, (Chitu, et al., 2012) in their paper disputed the traditional opinion that pound sterling remained the dominant international currency throughout the interwar years and even for a brief period after the World War II. These authors underlined that one of the main causes behind the change in the sterling position within the world finance is directly related to the rapid financial market development. Stemming from the data on the currency denomination of foreign public debt in 33 countries over the period of 1914-1946, the authors tries to prove that the US dollar was emerging as the next leading currency, thereby shifting pound sterling to the lower position in significance. Conclusions obtained by these researchers let them cast some doubt on the three main principles behind international currencies as such.

First and foremost, they demonstrated that pound sterling was overtaken by dollar 15 years prior to the date that some other sources indicate, namely in 1929. Thereafter, (Chitu, et al., 2012) put forward the assumption that if the monetary leadership position is once lost, it would not be always forever. They justified this statement by stating that in spite of losing its dominance in the late 1920s, pound sterling then managed to recover after 1933 and then was actively used alongside the US dollar until the end of the same decade.

Lastly, the analysts challenge the hypothesis that there is a space for only one dominant international currency. Applying a tobit model, the researchers received empirical results which show that their three assumptions regarding international currency tendencies are correct. Moreover, they found a real reason why the role of pound sterling has changed in the world of finance. According to their results, quick development of American financial markets was the actual driving force that helped the US dollar take the leading position and 
push pound sterling from being the first preferred reserve currency to being the second one. Part of these results can be also supported visually (see Fig. 1).

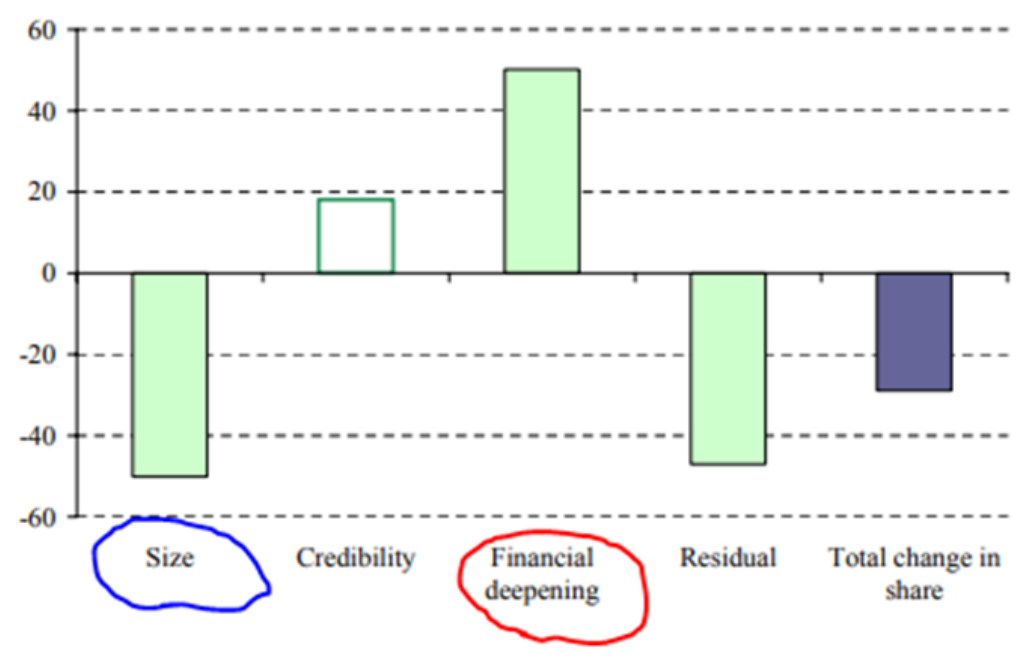

Figure 1 - Changes in the share of pound sterling in the global foreign public debt between 1918 and 1932 (in \%)

(Source: Data of European Central Bank)

Fig. 1 above shows the estimations for pound sterling. The authors in their paper state that financial deepening had a positive impact on the increased share of pound sterling as a currency of denomination for international bonds. However, at the same time, the country size factor had a bigger impact (and a negative one). Therefore, the fall in the average share of pound sterling between 1918 and 1932 was from 13\% in 1918 to 8\% in 1932. These results and numbers are corresponding to those in other books, together they show how slow growth and high unemployment hindered Britain's efforts to maintain its financial dominance and undermined the role of pound sterling during the 1920s.

In (Schenk, 2015), the author has a different position which is: the pound sterling was surpassed by the US dollar after the World War II, namely, straight in 1945. This author points out that after the War, the US dollar became the leading international currency for any worldwide economic situation and majority of wealthy nations pegged their currencies to the USD, meanwhile USD valued itself in gold. Nevertheless, (Schenk, 2015) agreed with (Chitu et al., 2012) that more than one basic reserve currency could operate at the same time over a long period, but also explained it in a different way.

In (Schenk, 2015) the author's opinion is that in dollar-sterling case it became possible because during the post-war time the supply of USD assets and gold was likely to be restricted by the US balance of payments surpluses. Furthermore, this author is referring to the International Monetary Fund data and the fact that in the early post-war period pound sterling reserves were 4 times the value of the USD reserves, and by 1947 pound sterling accounted for $87 \%$ of the worldwide foreign exchange reserves. It took 10 years after the War for the share of US dollar reserves to surpass pound sterling. Analysis done by this 


\section{ANALYSIS OF THE CHANGING ROLE OF POUND}

researcher completely contradicts the conclusions obtained by (Chitu et al., 2012).

According to (Schenk, 2015), the real dominance of USD along with the pound sterling recession took place much later than it was stated by the previous authors, 9-10 years after the World War II was finished. (Schenk, 2015) also supplemented their analysis with the chart of distribution which you can find below in Figure 2.

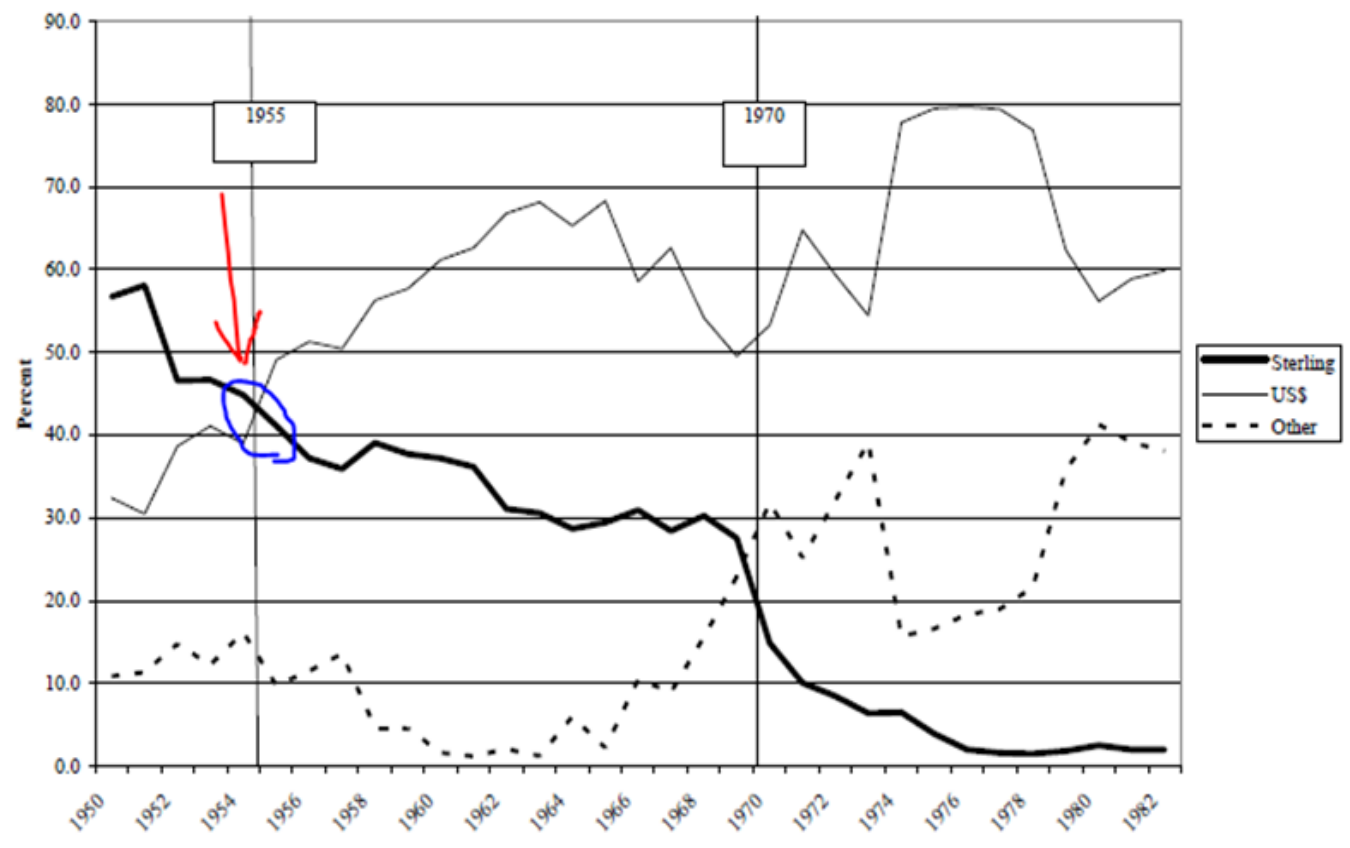

Figure 2 - Currency Distribution of Foreign Exchange Reserves (1950-1982) (Source: International Monetary Fund)

In this Figure 2 we can obviously see the actual point in which the change in positions between USD and pound sterling took place.

\section{Methodology}

To answer the hypothesis questions raised at the beginning of this paper, it is important to turn to research philosophy. It is well known that usually authors adhere to a specific philosophy, thus, in this paper positivism research philosophy is applied. From this philosophical approach it follows that quantitative research strategy should be used, which is mainly focused on finding a definite answer by means of numerical or mathematical data. In regards to data collection, all necessary information is obtained from secondary data sources (websites, books, databases and journals), primarily because such type of data is open for usage and is easy to obtain (Wilson, 2014).

Variables presented in the table above are important components of our research, and all further results and inferences will be based on their indicators. Data for this study has been collected from different databases, including the International Monetary Fund (IMF) and the Bank of England. 


\section{Analysis and Results}

After the thorough analysis of various articles regarding the changing role of pound sterling within the IMS, we can claim that both groups of authors have truth in their affirmations, but we are more inclined to support the position as in (Chitu et al., 2012).

This section of our research will explain why we reject the alternative hypothesis in favour to our null hypothesis.

The pound sterling was the main international currency until 1914. At that time, the majority of developed countries pegged their currencies into gold to create stability in their currency exchange. The Bank of England used to perform the role of the central bank for the whole world and was, unofficially, in charge of the international gold standard through interest rates. The specie-flow mechanism controlled the system of exchange rates. If a currency became overvalued, gold would flow out of that country into other countries, thereby putting the exchange rate back to its normal level (Global Financial Data, 2014).

The gold standard operated well until August 1914 when the World War I put many countries in the conditions, where they had to stop their currency conversion. Countries were then free to print money that they were not able to raise through taxes, in order to continue participating in the World War I. This led to high and varying rates of inflation. Meanwhile the Federal Reserve Bank was created as a logical response to the insecurity and instability of the currency system based on banknotes issued by individual banks. During that period the US economy overtook British one to become the world's largest economy. Three years later, Britain found itself in a position of a borrower, for the first time. By 1919, Britain had to renounce the gold standard, and this decision destroyed the bank accounts of international merchants who then traded in sterling pounds. This was the time when the US dollar replaced sterling pound as the leading reserve in the world (Investopedia, 2020).

It is extremely hard to find data and solid evidence for that period. However, we have managed to find at least one important indicator of the pound sterling behaviour after the both world wars.

We can conclude here that pound sterling was quite volatile and unstable, frequent fluctuations on the chart above prove this. After the World War I pound sterling started to experience difficulties, but later it was able to recover its stable position and stay afloat. However, the start of the World War II became a massive hit on this already much weakened currency. A significant drop in the value of the pound with the outbreak of WWII led the British government to peg the value of the pound to the dollar. This was a turning point for the sterling and its position in the International monetary system.

\section{Conclusion}

The research conducted and presented in this article allowed us to answer two main questions:

When did pound sterling lose its financial dominance? And why did this happen?

Some researchers claim that pound sterling lost its dominance as the key currency of the world back in 1929, while others state that it was overtaken by the US dollar much later, after the World War II already.

We cannot really determine the exact year, much less the exact date, when this

happened. In our opinion, a combination of many circumstances has gradually led to this 


\section{ANALYSIS OF THE CHANGING ROLE OF POUND}

change in currencies' positions. Although the role of the reserve currency was historically assigned to pound sterling, this currency failed to resist successfully to all the difficulties which followed one after another, thus, it became unstable.

The American side used this situation wisely and promptly, taking the leading position thanks to a properly chosen strategy. Under the USA pressure, the US dollar standard was established within the Bretton Woods system. Dollar became the only currency convertible into gold, therefore, it also became the basis for currency parities, currency interval and reserve assets.

\section{References:}

Chitu, L., Eichengreen, B. \& Mehl, A. (2012). When Did The Dollar Overtake Sterling As The Leading International Currency? Working Paper Series, 1433. 1-43.

Global Financial Data (2014). History of Universal Currencies. Available at: http://www.globalfinancialdata.com/a-history-of-universal-currencies/

Investopedia (2020). How the U.S. Dollar Became the World's Reserve Currency. Available at: https://www.investopedia.com/articles/forex-currencies/092316/how-us-dollar-became-worldsreserve-currency.asp

Schenk, C. R. (2015). The Retirement of Sterling as a Reserve Currency after 1945: Lessons for the US Dollar. Available at: https://www.researchgate.net/publication/229048743_The_Retirement_of_Sterling_as_a_Reser ve_Currency_after_1945_Lessons_for_the_US_Dollar

Södersten, B. \& Reed, G. (2015). The International Monetary System. Available at: https://link.springer.com/chapter/10.1007\%2F978-1-349-23320-5_31

Wilson, J. (2014). Essentials of Business Research: a guide to doing your research project. 2nd edition. London: SAGE.

World Economic Forum (2016). A short history of the British pound. Available at: https://www.weforum.org/agenda/2016/06/a-short-history-of-the-british-pound/

Paper submitted

Paper accepted for publishing

Paper published online
06 May 2020

21 July 2020

31 July 2020 